\title{
Validation of transgenic models of breast cancer: ductal carcinoma in situ (DCIS) and Brca1-mutation-related breast cancer
}

\author{
M. S. Frech ${ }^{\star}$, L. P. Jones ${ }^{\star}$, P. A. Furth \\ Lombardi Comprehensive Cancer Center, Department of Oncology, Georgetown University, \\ Washington, DC, USA.
}

\begin{abstract}
Available mouse models of ductal carcinoma in situ (DCIS) and BRCA1-mutation-related breast cancer are reviewed. The best validated mouse models of human DCIS are the conditional estrogen receptor $\alpha$ in mammary tissue (CERM) model initiated by deregulated estrogen receptor $\alpha$ and the serial explant mouse model initiated by p53 deficiency. At present the most useful and best validated mouse model of BRCA1-mutationrelated breast cancer uses the cre-lox system to make a conditional Brca1 deletion targeted to mammary epithelial cells. The major shortcoming of the non-conditional Brca1 models is the high incidence of non-mammary tumor development. The use of mammary gland transplants or explants from these mice into nude hosts is one approach that could be used to circumvent this deficiency. Development and validation of a Brca1-mutationrelated mouse model of basal cell breast cancer is an important next step.
\end{abstract}

Keywords: Brca1; Breast cancer; DCIS; ER $\alpha$; Mouse models

\section{Introduction}

In developed countries breast cancer is diagnosed in as many as 1 of 8 women at sometime during their lifetimes. As breast cancer can be managed successfully when it is diagnosed and treated at pre-invasive stages, there is enormous clinical interest in finding better ways to identify women who are at high risk for invasive cancer. Understanding the pathophysiology of human breast cancer is a key factor that can be used to develop improved means of identifying and treating women at high risk in order to prevent the development of invasive breast cancer. Genetically manipulated mouse models are one approach to study breast cancer pathophysiology. Specific genetic changes

\footnotetext{
"M. S. Frech and L. P. Jones contributed equally to this article.
}

Correspondence to: Priscilla A. Furth, Lombardi Comprehensive Cancer Center, Department of Oncology, Georgetown University, New Research Building, Room E520A, 3970 Reservoir Road, Washington, DC 20057, USA E-mail: paf3@georgetown.edu; Tel: +1 202687 8682; Fax: +1 2026877505 Publication date 31/08/05 $\mathrm{BCO} / 313 / 2004 / \mathrm{FO}$ can be engineered into the mice with development of the disease occurring within the context of normal physiological function and without exogenous chemical carcinogens or radiation exposure.

A non-invasive neoplastic condition that is known to predispose women to the development of invasive breast cancer is Ductal Carcinoma In Situ (DCIS) [1]. The molecular cause(s) of DCIS remain unidentified, but to date investigators have correlated the appearance of DCIS with increased estrogen receptor alpha $(E R \alpha)$ expression [2,3] and telomere shortening [4]. One or both events may be a critical early event in neoplastic progression, the first leading to alterations in cell proliferation and the second predisposing to development of genetic instability. Seventy five percent of all cases of human DCIS are ER $\alpha$ positive $[5,6] . E R \alpha$ is expressed in $100 \%$ of non-comedo DCIS and over $90 \%$ of cells in those lesions express $\mathrm{ER} \alpha$. The remaining $25 \%$ of DCIS that do not express the receptor are predominantly high-grade comedo lesions.

Genetic diseases in which germline mutations predispose women to the development of DCIS and 
invasive breast cancer are BRCA1 and BRCA2 mutation [7-10], Cowden's syndrome [11,12] and Li-Fraumeni syndrome [13]. Loss of Brca1 function has been associated with both genetic instability and enhanced estrogen signaling [14-19]. BRCA1associated breast cancers are frequently $\mathrm{ER} \alpha$, ErbB2 and cyclin D1 negative, are defined as high grade and demonstrate p53 expression [14,20-22]. An overrepresentation of BRCA1-mutation-related adenocarcinomas has been described within the category of basal epithelial cell mammary cancers suggesting that loss of BRCA1 function potentiates development of this specific type of breast cancer $[23,24]$.

\section{Mouse models of DCIS}

To date three models have been identified that develop human-like DCIS histopathology (Table 1): a Conditional Estrogen Receptor $\alpha$ in Mammary tissue (CERM) model: mouse mammary tumor virus (MMTV)-rtTA/tet-op-ER $\alpha$ mice [25], a WAP-TAg model [26], and a serial mammary tissue explant mouse model with p53 deficiency in the Balb/C strain background [27]. These models present four different types of DCIS that are found in humans: cribiform, clinging, solid and comedo $[28,29]$.

In the CERM model increasing steady-state levels of nuclear-localized $\mathrm{ER} \alpha$ in mammary epithelial cells combined with an inability to downregulate $E R \alpha$ expression in response to estrogen exposure is correlated with the development of DCIS. This mechanism is consistent with one of the proposed etiology of human DCIS; that is, in women, increased levels of nuclear localized ER $\alpha$ in mammary epithelial cells of ductal hyperplasia and DCIS is correlated with an increased risk of developing $\mathrm{ER} \alpha$ positive invasive breast cancer [2]. This is the only mouse model of human-like DCIS in which lesion development is not dependent upon expression of an oncogene or deletion of a tumor suppressor gene. In this model, over-expression of ER $\alpha$ induces increased rates of mammary epithelial cell proliferation and DCIS lesions develop as early as 2 months of age and hyperplastic nodules appear by 12 months of age. The DCIS lesions in this model express ER $\alpha$ and progesterone receptor (PR). Gene and protein expression profiles were used to validate CERM mice as a model of ER $\alpha$ and PR positive DCIS. Lesion development in the CERM model is hormone dependent as the lesions regress in response to anti-estrogen treatment and ovarian function is required for lesion development. The murine DCIS lesions demonstrate expression of nuclear localized cyclin D1 and p27, similar to ER $\alpha$ positive DCIS lesions in humans [30-32]. To date all studies of the CERM model have been carried out in the C57BI/6 strain background.

The WAP-TAg model develops cribiform-, roman arch-like-, clinging- and comedo-type DCIS [26]. Lesion development is dependent upon SV40 Taginduced inactivation of tumor suppressor genes including pRb and p53 and cell cycle control pathways [33]. p53 mutations [34-36] and deregulation of p16-cyclin D-Cdk4(6)-pRB-E2F and p14/ARF pathways have been described in human DCIS lesions [37-39]. However, in this model, lesion development is dependent upon pregnancy-induced expression of

Table 1. Transgenic mouse models of DCIS.

\begin{tabular}{|c|c|c|c|c|c|}
\hline $\begin{array}{l}\text { Model/mouse } \\
\text { strain }\end{array}$ & Histopathology & $\begin{array}{l}\text { Initiating event/ } \\
\text { model type }\end{array}$ & $\begin{array}{l}\text { Relationship to } \\
\text { human DCIS }\end{array}$ & $\begin{array}{l}\text { Gene expression } \\
\text { in the DCIS }\end{array}$ & Reference \\
\hline $\begin{array}{l}\text { CERM transgenic } \\
\text { mice/C57B1/6 }\end{array}$ & $\begin{array}{l}\text { Ductal hyperplasia, } \\
\text { lobular hyperplasia, } \\
\text { cribiform, clinging } \\
\text { and solid DCIS }\end{array}$ & $\begin{array}{l}\text { Over-expression and } \\
\text { deregulation of ER } \alpha \text { in } \\
\text { mammary epithelial cells/ } \\
\text { conditional tetracycline } \\
\text { responsive gene targeting to } \\
\text { mammary epithelial cells/ } \\
\text { disease in nulliparous mice }\end{array}$ & $\begin{array}{l}\text { Increased and } \\
\text { deregulated ER } \alpha \\
\text { expression is found } \\
\text { in the majority of } \\
\text { human DCIS }\end{array}$ & $\begin{array}{l}\text { ER } \alpha / P R / p 27 \\
\text { positive, increase } \\
\text { in nuclear- } \\
\text { localized cyclin D1 }\end{array}$ & [25] \\
\hline $\begin{array}{l}\text { WAP-TAg } \\
\text { transgenic } \\
\text { mice/BALB/c }\end{array}$ & $\begin{array}{l}\text { Cribiform-, roman } \\
\text { arch-like-, clinging-, } \\
\text { and comedo-type } \\
\text { DCIS }\end{array}$ & $\begin{array}{l}\text { SV40 TAg expression in } \\
\text { mammary epithelial cells/ } \\
\text { targeting to mammary epithelial } \\
\text { cells/pregnancy-induced lesion } \\
\text { development in } 5 \text { of } 6 \text { lines }\end{array}$ & $\begin{array}{l}\text { Loss of p53 function } \\
\text { and deregulation of } \\
\text { p16-pRb pathway } \\
\text { are found in some } \\
\text { human DCIS }\end{array}$ & $\begin{array}{l}\text { No information } \\
\text { available }\end{array}$ & [26] \\
\hline $\begin{array}{l}\text { p53 null and } \\
\text { heterozygous } \\
\text { mammary } \\
\text { explants in } \\
\text { nude mice/ } \\
\text { BALB/c explants }\end{array}$ & $\begin{array}{l}\text { Cribiform- and } \\
\text { comedo-type } \\
\text { DCIS }\end{array}$ & $\begin{array}{l}\text { Loss of functional p53 in } \\
\text { mammary epithelial cells/serial } \\
\text { transplantation of p53 null } \\
\text { and heterozygote mammary } \\
\text { tissue into nude mice }\end{array}$ & $\begin{array}{l}\text { Loss of functional p53 } \\
\text { is found in } 20-50 \% \\
\text { of human DCIS }\end{array}$ & $\begin{array}{l}\text { Information } \\
\text { available only } \\
\text { on outgrowth } \\
\text { lines from DCIS }\end{array}$ & {$[27]$} \\
\hline
\end{tabular}


the TAg oncogene in 5 of 6 lines, whereas in humans pregnancy is described as a protective factor [40]. In addition, because the WAP promoter is active in the alveolar epithelium in this model, lesion development is thought to arise from alveolar cells rather than ductal cells. In contrast, in human disease there is more concern about the lesions arising from the ductal epithelium in non-pregnant women. There is no published information available on gene and protein expression profiles in the WAP-Tag model. The studies described above using the WAP-TAg model were carried out in the BALB/c strain background.

The p53-deficient model consists of a series of serially transplanted premalignant outgrowth lines derived from p53 null and heterozygous mice in the Balb/C strain background. DCIS arises after 5 to 8 serial transplantations. The initiating event in this model is inactivation of p53 function. Loss of functional p53 is found in some patients at risk for breast cancer (Li-Fraumeni syndrome) and in $20-50 \%$ cases of human DCIS [34-36]. Loss of genetic stability has been described in human DCIS lesions $[37,41]$. Genetic instability can result in aneuploidy. In this model, investigators characterized different outgrowth lines with and without aneuploidy. Both diploid and aneuploid outgrowths were found to go on to develop DCIS. The presence or absence of aneuploidy specifically in the DCIS lesions that developed were not examined. Telomerase activity was higher in outgrowth lines but was not directly evaluated in the DCIS lesions. ER $\alpha$ immunohistochemistry has been performed on the outgrowth lines but not specifically in the DCIS lesions. Nine of 11 outgrowth lines show ER $\alpha$ expression levels equal or greater than normal mammary gland without p53 mutation. Two of the 11 outgrowth lines show ER $\alpha$ expression levels lower than normal levels.

There are two genetically manipulated mouse models that develop non-invasive Mammary Intraepithelial Neoplasia (MIN) [42] lesions that are biologically but not histopathologically similar to human DCIS: the C3(1)/SV40 Tag on an FVB/N background $[43,44]$ and the polyoma middle $T$ on an FVB background $[45,46]$. The MIN lesions that develop in the C3(1)/SV40 Tag transgenic mouse model lose ER $\alpha$ expression as they progress to less differentiated lesions indicating that this may be a more valid model for $\mathrm{ER} \alpha$ negative MIN as compared to $\mathrm{ER} \alpha$ positive disease. Cancer development in this model can include amplification of the Ki-ras gene; however, amplification of this gene is not specifically associated with DCIS or invasive breast cancer in humans.

An alternative to the use of genetically manipulated mouse models to study the pathophysiology of DCIS is a xenograft model derived from human mammary epithelial cells that are implanted in nude mice. The DCIS lesions that develop histopathologically resemble human disease [47].

\section{Mouse models of Brca1-mutation-related breast cancer}

Brca1-deficient homozygous knockout mouse models result in early embryonic lethality due to developmental abnormalities and cellular proliferation defects [48-51]. To date, three different approaches have been used to generate Brca1-mutation-related mouse models (Table 2). All of these models depend upon interruption of exon 11 to disrupt Brca1 function. The protein domain encoded by exon 11 is required for many of the cellular functions ascribed to Brca1 [52]. There are mouse strain differences in the impact of Brca1 disruption on embryonic development.

A cre-lox-based approach is used to direct a targeted deletion of Brca1 exon 11 to mammary epithelial cells and thereby avoid embryonic toxicity (Brca1 conditional (co/co)/MMTV-Cre/p53 $3^{+/-}$mice) [52,53]. These mice continue to express the normal splice variant of Brca1 that lacks exon 11 in the targeted cells. Similar to human BRCA1-mutation-related breast cancers, a significant percentage of mammary adenocarcinomas developed in these mice are classified as high-grade undifferentiated adenocarcinomas, demonstrate loss of p53 function and both the cancers and precancerous hyperplastic lesions are $\mathrm{ER} \alpha$ negative [53,54]. Unlike human BRCA1mutation-related cancers, ErbB2 and cyclin D1 overexpression are described in a significant proportion of these cancers, and c-myc over-expression also can be found $[53,54]$. Mammary cancer incidence in this model is very low when both p53 alleles are intact but is increased significantly by p53 haploinsufficiency [52]. In the Brca $1^{\mathrm{co} / \mathrm{co}} / \mathrm{MMTV}-\mathrm{Cre} / \mathrm{p} 53^{+/-}$ mice, hyperplastic nodules and foci composed of highly proliferative mammary epithelial cells appear at least 2-6 months before development of adenocarcinomas and the prevalence of these abnormalities increases with age [54]. While tumor development is generally solitary, all glands can demonstrate varying numbers of hyperplastic nodules and foci. Metastatic disease to the liver and lung are found in some although not all mice with mammary adenocarcinomas. The majority of palpable adenocarcinomas appear between 6 and 18 months of age. Significantly, mammary cancers do not develop in mice that have only one Brca1 allele disrupted, only in mice with both alleles disrupted. This stands in contrast to human disease, which is believed to initiate in mammary epithelial cells with BRCA1 haploinsufficiency.

An alternative approach is to generate a mouse model more similar to human disease in which mammary cancer development is initiated by Brca1 
Table 2. Transgenic mouse models of $B R C A 1$-mutation-related breast cancer.

\begin{tabular}{|c|c|c|c|c|c|}
\hline $\begin{array}{l}\text { Model/mouse } \\
\text { strain }\end{array}$ & Histopathology & $\begin{array}{l}\text { Initiating event/ } \\
\text { model type }\end{array}$ & $\begin{array}{l}\text { Relationship to initiation } \\
\text { of human BRCA1- } \\
\text { mutation-related disease }\end{array}$ & $\begin{array}{l}\text { Gene expression in } \\
\text { mammary cancers }\end{array}$ & Reference \\
\hline $\begin{array}{l}\text { Brca1co/co/ } \\
\text { MMTV-Cre/p53 } 3^{+/-} / \\
\text {C57B1/6 }\end{array}$ & $\begin{array}{l}\text { Mammary } \\
\text { hyperplasia, } \\
\text { hyperplastic } \\
\text { nodules, } \\
\text { undifferentiated } \\
\text { mammary } \\
\text { adenocarcinomas }\end{array}$ & $\begin{array}{l}\text { Loss of full-length } \\
\text { Brca1 through } \\
\text { exon } 11 \text { deletion } \\
\text { with } p 53 \\
\text { haploinsufficiency/ } \\
\text { conditional } \\
\text { cre-lox targeting } \\
\text { to mammary } \\
\text { epithelial cells/ } \\
\text { disease in } \\
\text { nulliparous mice }\end{array}$ & $\begin{array}{l}\text { Human disease is initiated by } \\
\text { a spectrum of heterozygous } \\
\text { Brca1 mutations. p53 } \\
\text { mutation found in } \sim 50 \%\end{array}$ & $\begin{array}{l}\text { ER } \alpha / P R \text { negative, } \\
\text { ErbB2, cyclin D1 } \\
\text { and c-myc over- } \\
\text { expression in a subset }\end{array}$ & {$[53,54]$} \\
\hline $\begin{array}{l}\mathrm{Brca1}^{+/-} / \\
\mathrm{p} 53^{-/-} \text {and } \\
\mathrm{Brca1}^{+/-} / \\
\mathrm{p} 53^{+/-} \text {with } \\
\text { irradiation at } \\
\text { age 4-6 } \\
\text { weeks/strain } \\
\text { not specified }\end{array}$ & $\begin{array}{l}\text { Papillary, tubular, } \\
\text { intraductal, } \\
\text { anaplastic, } \\
\text { unclassifiable } \\
\text { mammary } \\
\text { cancers }\end{array}$ & $\begin{array}{l}\text { Targeted mutation to } \\
\text { exon } 11 \text { in one Brca1 } \\
\text { allele with either loss } \\
\text { of p53 or p53 } \\
\text { haploinsufficiency/ } \\
\text { germline mutation }\end{array}$ & As above & $\begin{array}{l}\text { Loss of wild-type } \\
\text { Brca1 expression } \\
\text { in a subset }\end{array}$ & [55] \\
\hline $\begin{array}{l}\text { Brca } 1^{\text {tr } / \text { tr }} \text { and } \\
\text { Brca } 1^{\text {tr/tr/ }} / \\
\text { p53 } \\
129 / \text { Sv or MF1 }\end{array}$ & $\begin{array}{l}\text { Infrequent } \\
\text { preneoplasia and } \\
\text { DCIS, solid, } \\
\text { papillary, cribiform, } \\
\text { tubular, acinar, } \\
\text { mucinous, adeno- } \\
\text { acanthomatous, } \\
\text { sarcomatous } \\
\text { mammary cancers }\end{array}$ & $\begin{array}{l}\text { Loss of full-length } \\
\text { Brca1 through } \\
\text { introduction of a } \\
\text { STOP codon into } \\
\text { exon } 11 \text { with and } \\
\text { without p53 } \\
\text { haploinsufficiency/ } \\
\text { germline mutation }\end{array}$ & As above & $\begin{array}{l}\text { Most ER } \alpha / P R \\
\text { negative, many } \\
\text { p53, p21 and } \\
\text { cyclin D1 positive, } \\
\text { ErbB2 in a subset }\end{array}$ & {$[57]$} \\
\hline
\end{tabular}

haploinsufficiency. However because cancer development does not occur in the mammary gland secondary to loss of one Brca1 allele, disruption of one Brca1 allele is combined with loss of either one (heterozygote) or two (null) p53 alleles and exposure to 5 Gray (Gy) of ionizing radiation at 4-6 weeks of age [55]. The utility of these models is compromised by the high incidence of lymphomas and other nonmammary cancers that develop in these mice. In the p53 null mice, $10 \%$ (4/41) of mice with Brca1 haploinsufficiency $\left(\mathrm{Brca}^{+/-} / \mathrm{p} 53^{-/-}\right.$) develop mammary cancers (reported as papillary, tubular or unclassifiable), but $90 \%$ (36/41) develop lymphomas or other non-mammary solid tumors. If the mice are $p 53$ heterozygotes then irradiation is required to induce mammary cancer development. In the absence of radiation there are no mammary cancers, but $25 \%$ (5/21) of irradiated $B r c a 1^{+/-} / p 53^{+/-}$mice develop mammary cancers. Similar to the $B r c a 1^{+/-} / p 53^{-1-}$ mice the usefulness of this model is compromised by the fact that $95 \%(23 / 24)$ of the mice develop lymphomas or other non-mammary solid tumors. Loss of wild-type Brca1 expression is described in a subset of the mammary cancers just as loss of heterozygosity $(\mathrm{LOH})$ at the BRCA1 locus found in human disease [56]. Expression patterns of $\mathrm{ER} \alpha$, $\mathrm{PR}$, ErbB2 or other markers in the mammary cancers that develop in these models have not yet been reported.

A third approach is to modify the Brca1 locus so that a truncated mutant protein that maintains embryonic development is expressed but the C-terminal half of Brca1 required for its tumor suppressor effects is lost (Brca ${ }^{\text {tr }} / \mathrm{BrCa}^{\text {tr }}$ mice) [57]. It is important to note that this truncated protein maintains embryonic development only in specific mouse strains (129/Sv or MF1). Mammary cancers develop in 16\% (12/76) of the mice but $85 \%$ (76/89) develop lymphomas or other non-mammary solid tumors compromising the utility of the model. The percentage of mice developing mammary cancers is not significantly increased by deletion of one p53 allele (2/7) and no mammary cancers develop in p53 null mice (0/8). One hundred percent of both $p 53$ heterozygote and null $\mathrm{Brca}^{\text {tr }} / \mathrm{Brca}^{\text {tr }}$ mice develop lymphomas or other nonmammary solid tumors. Both mammary preneoplasia and cancer are described in the Brca ${ }^{\text {tr }} / \mathrm{Brca}^{\text {tr }}$ mice but extensive proliferative mammary disease is uncommon. Mammary cancers demonstrate solid, papillary, cribriform, tubular, acinar, mucinous, 
adenoacanthomatous, and sarcomatous pathology. The majority of the mammary cancers are ER $\alpha$ and PR negative, frequently p53, p21 and cyclin D1 positive with 1/3 demonstrating ErbB2 expression.

\section{Acknowledgements}

Sources of support: NCl, NIH, NO1-CN-25003-44 (P.A.F.), NCl, NIH, R01 CA89041 (P.A.F.), Susan G. Komen Breast Cancer Foundation PDF0402444 (L.P.J., P.A.F.), Department of Defense Breast Cancer Research Program DAMD 05-1-0302 (M.S.F.).

\section{References}

1. Cotran RS, Kumar V, Collins T. Pathologic Basis of Disease, 6th edition. Philadelphia, PA: W.B. Saunders Company; 1999.

2. Shoker BS, Jarvis C, Sibson DR, Walker C, Sloane JP. Oestrogen receptor expression in the normal and precancerous breast. J Pathol 1999; 188: 237-244.

3. Pike MC, Spicer DV, Dahmoush L, Press MF. Estrogens, progestogens, normal breast cell proliferation, and breast cancer risk. Epidemiol Rev 1993; 15: 17-35.

4. Meeker AK, Argani P. Telomere shortening occurs early during breast tumorigenesis: a cause of chromosome destabilization underlying malignant transformation? J Mammary Gland Biol Neoplasia 2004; 9: 285-296.

5. Barnes R, Masood S. Potential value of hormone receptor assay in carcinoma in situ of breast. Am J Clin Pathol 1990; 94: 533-537.

6. Allred DC, Mohsin SK. Biological features of premalignant disease in the human breast. J Mammary Gland Biol Neoplasia 2000; 5(4): 351-364.

7. Claus EB, Petruzella S, Matloff E, Carter D. Prevalence of BRCA1 and BRCA2 mutations in women diagnosed with ductal carcinoma in situ. JAMA 2005; 293: 964-969.

8. Kauff ND, Brogi E, Scheuer L, et al. Epithelial lesions in prophylactic mastectomy specimens from women with BRCA mutations. Cancer 2003; 97: 1601-1608.

9. Hamilton LJ, Evans AJ, Wilson AR, et al. Breast imaging findings in women with BRCA1- and BRCA2-associated breast carcinoma. Clin Radiol 2004; 59: 895-902.

10. Komenaka IK, Ditkoff BA, Joseph KA, et al. The development of interval breast malignancies in patients with BRCA mutations. Cancer 2004; 100: 2079-2083.

11. Lynch ED, Ostermeyer EA, Lee MK, et al. Inherited mutations in PTEN that are associated with breast cancer, cowden disease, and juvenile polyposis. Am J Hum Genet 1997; 61: 1254-1260.

12. Schrager CA, Schneider D, Gruener AC, Tsou HC, Peacocke M. Clinical and pathological features of breast disease in Cowden's syndrome: an underrecognized syndrome with an increased risk of breast cancer. Hum Pathol 1998; 29: 47-53.

13. Thor AD, Moore II DH, Edgerton SM, et al. Accumulation of p53 tumor suppressor gene protein: an independent marker of prognosis in breast cancers. J Nat/ Cancer Inst 1992; 84: 845-855.

14. Narod SA, Foulkes WD. BRCA1 and BRCA2: 1994 and beyond. Nat Rev Cancer 2004; 4: 665-676.
15. Adem C, Soderberg CL, Hafner K, et al. ERBB2, TBX2, RPS6KB1, and MYC alterations in breast tissues of BRCA1 and BRCA2 mutation carriers. Gene Chromosome Cancer 2004; 41: 1-11.

16. Razandi M, Pedram A, Rosen EM, Levin ER. BRCA1 inhibits membrane estrogen and growth factor receptor signaling to cell proliferation in breast cancer. $\mathrm{Mol}$ Cell Biol 2004; 24: 5900-5913.

17. Mote PA, Leary JA, Avery KA, et al. Germ-line mutations in BRCA1 or BRCA2 in the normal breast are associated with altered expression of estrogen-responsive proteins and the predominance of progesterone receptor A. Gene Chromosome Cancer 2004; 39: 236-248.

18. Fan S, Ma YX, Wang C, et al. p300 modulates the BRCA1 inhibition of estrogen receptor activity. Cancer Res 2002; 62: 141-151.

19. Fan S, Ma YX, Wang C, et al. Role of direct interaction in BRCA1 inhibition of estrogen receptor activity. Oncogene 2001; 20: 77-87.

20. Lakhani SR, Van De Vijver MJ, Jacquemier J, et al. The pathology of familial breast cancer: predictive value of immunohistochemical markers estrogen receptor, progesterone receptor, HER-2, and p53 in patients with mutations in BRCA1 and BRCA2. J Clin Oncol 2002; 20: 2310-2318.

21. Armes JE, Trute L, White $D$, et al. Distinct molecular pathogeneses of early-onset breast cancers in BRCA1 and BRCA2 mutation carriers: a population-based study. Cancer Res 1999; 59: 2011-2017.

22. Noguchi S, Kasugai T, Miki Y, et al. Clinicopathologic analysis of BRCA1- or BRCA2-associated hereditary breast carcinoma in Japanese women. Cancer 1999; 85: 2200-2205.

23. Foulkes WD, Stefansson IM, Chappuis PO, et al. Germline BRCA1 mutations and a basal epithelial phenotype in breast cancer. J Nat/ Cancer Inst 2003; 95: 1482-1485.

24. Sorlie T, Tibshirani R, Parker J, et al. Repeated observation of breast tumor subtypes in independent gene expression data sets. Proc Natl Acad Sci USA 2003; 100: 8418-8423.

25. Frech MS, Halama ED, Tilli MT, et al. Deregulated estrogen receptor alpha expression in mammary epithelial cells of transgenic mice results in the development of ductal carcinoma in situ. Cancer Res 2005; 65: 681-685.

26. Schulze-Garg C, Lohler J, Gocht A, Deppert W. A transgenic mouse model for the ductal carcinoma in situ (DCIS) of the mammary gland. Oncogene 2000; 19: 1028-1037.

27. Medina D, Kittrell FS, Shepard A, et al. Biological and genetic properties of the p53 null preneoplastic mammary epithelium. FASEB J 2002; 16: 881-883.

28. Leonard GD, Swain SM. Ductal carcinoma in situ, complexities and challenges. J Natl Cancer Inst 2004; 96 906-920.

29. Rosser RJ. Consensus conference on the classification of ductal carcinoma in situ. Cancer 1998; 82: 2293-2295.

30. Alle KM, Henshall SM, Field AS, Sutherland RL. Cyclin D1 protein is overexpressed in hyperplasia and intraductal carcinoma of the breast. Clin Cancer Res 1998; 4: 847-854.

31. Weinstat-Saslow D, Merino MJ, Manrow RE, et al. Overexpression of cyclin D mRNA distinguishes invasive and in situ breast carcinomas from non-malignant lesions. Nat Med 1995; 1: 1257-1260. 
32. Oh YL, Choi JS, Song SY, et al. Expression of p21Waf1, p27Kip1 and cyclin D1 proteins in breast ductal carcinoma in situ: relation with clinicopathologic characteristics and with p53 expression and estrogen receptor status. Pathol Int 2001; 51: 94-99.

33. Furth PA. SV40 rodent tumour models as paradigms of human disease: transgenic mouse models. Dev Biol Stand 1998; 94: 281-287.

34. Lebeau A, Unholzer A, Amann G, et al. EGFR, HER2/neu, cyclin D1, p21 and p53 in correlation to cell proliferation and steroid hormone receptor status in ductal carcinoma in situ of the breast. Breast Cancer Res Treat 2003; 79: 187-198.

35. Ho GH, Calvano JE, Bisogna M, et al. In microdissected ductal carcinoma in situ, HER-2/neu amplification, but not p53 mutation, is associated with high nuclear grade and comedo histology. Cancer 2000; 89: 2153-2160.

36. Keohavong P, Gao WM, Mady HH, Kanbour-Shakir A, Melhem MF. Analysis of p53 mutations in cells taken from paraffin-embedded tissue sections of ductal carcinoma in situ and atypical ductal hyperplasia of the breast. Cancer Lett 2004; 212: 121-130.

37. Ando $\mathrm{Y}$, Iwase $\mathrm{H}$, Ichihara $\mathrm{S}$, et al. Loss of heterozygosity and microsatellite instability in ductal carcinoma in situ of the breast. Cancer Lett 2000; 156: 207-214.

38. Marsh KL, Varley JM. Frequent alterations of cell cycle regulators in early-stage breast lesions as detected by immunohistochemistry. Br J Cancer 1998; 77: 1460-1468.

39. Vestey SB, Sen C, Calder CJ, et al. p14ARF expression in invasive breast cancers and ductal carcinoma in situ relationships to $\mathrm{p} 53$ and $\mathrm{Hdm} 2$. Breast Cancer Res 2004; 6: R571-R585.

40. Sivaraman L, Medina D. Hormone-induced protection against breast cancer. J Mammary Gland Biol Neoplasia 2002; 7: 77-92.

41. Chin K, de Solorzano CO, Knowles D, et al. In situ analyses of genome instability in breast cancer. Nat Genet 2004; 36: 984-988.

42. Cardiff RD, Moghanaki D, Jensen RA. Genetically engineered mouse models of mammary intraepithelial neoplasia. J Mammary Gland Biol Neoplasia 2000; 5: 421-437.

43. Shibata MA, Liu ML, Knudson MC, et al. Haploid loss of bax leads to accelerated mammary tumor development in C3(1)/SV40-TAg transgenic mice: reduction in protective apoptotic response at the preneoplastic stage. EMBO J 1999; 18: 2692-2701.

44. Green JE, Shibata MA, Yoshidome $\mathrm{K}$, et al. The C3(1)/SV40 T-antigen transgenic mouse model of mammary cancer: ductal epithelial cell targeting with multistage progression to carcinoma. Oncogene 2000; 19: 1020-1027.

45. Maglione JE, Moghanaki D, Young LJ, et al. Transgenic polyoma middle-T mice model premalignant mammary disease. Cancer Res 2001; 61: 8298-8305.

46. Lin EY, Jones JG, Li P, et al. Progression to malignancy in the polyoma middle $T$ oncoprotein mouse breast cancer model provides a reliable model for human diseases. Am J Pathol 2003; 163: 2113-2126.

47. Miller FR. Xenograft models of premalignant breast disease. J Mammary Gland Biol Neoplasia 2000; 5: 379-391.

48. Bertwistle D, Ashworth A. Functions of the BRCA1 and BRCA2 genes. Curr Opin Genet Dev 1998; 8: 14-20.

49. Brugarolas J, Jacks T. Double indemnity: p53, BRCA and cancer. p53 mutation partially rescues developmental arrest in Brca1 and Brca2 null mice, suggesting a role for familial breast cancer genes in DNA damage repair. Nat Med 1997; 3: 721-722.

50. Deng CX, Scott F. Role of the tumor suppressor gene Brca1 in genetic stability and mammary gland tumor formation. Oncogene 2000; 19: 1059-1064.

51. Moynahan ME. The cancer connection: BRCA1 and BRCA2 tumor suppression in mice and humans. Oncogene 2002; 21: 8994-9007.

52. Xu X, Wagner KU, Larson D, et al. Conditional mutation of Brca1 in mammary epithelial cells results in blunted ductal morphogenesis and tumour formation. Nat Genet 1999; 22: 37-43.

53. Brodie SG, Xu X, Qiao W, et al. Multiple genetic changes are associated with mammary tumorigenesis in Brca1 conditional knockout mice. Oncogene 2001; 20: 7514-7523.

54. Jones LP, Li M, Halama ED, et al. Promotion of mammary cancer development by tamoxifen in a mouse model of Brca1-mutation-related breast cancer. Oncogene 2005; 24: 3554-3562.

55. Cressman VL, Backlund DC, Hicks EM, et al. Mammary tumor formation in p53- and BRCA1-deficient mice. Cell Growth Differ 1999; 10: 1-10.

56. Cavalli LR, Singh B, Isaacs C, Dickson RB, Haddad BR. Loss of heterozygosity in normal breast epithelial tissue and benign breast lesions in BRCA1/2 carriers with breast cancer. Cancer Genet Cytogenet 2004; 149: 38-43.

57. Ludwig T, Fisher P, Ganesan S, Efstratiadis A. Tumorigenesis in mice carrying a truncating Brca1 mutation. Gene Dev 2001; 15: 1188-1193. 